\title{
Rb-Sr MUSCOVITE AGE OF A PEGMATITE NEAR SIVAKKAVAARA, FINLAND
}

\author{
O. van BREEMEN and D. R. BOWES
}

\begin{abstract}
BREEMEN, O. van and BOWES, D. R. 1977: Rb-Sr muscovite age of a pegmatite near Sivakkavaara, Finland. Bull. Geol. Soc. Finland 49: $7-10$.

Isotopic analysis of five large books of muscovite from a pegmatite emplaced between the third and fourth deformational phases of the Svecokarelian orogenic episode indicate crystallization before 1880 m.y. with regional temperatures remaining elevated for about 120 m.y. The data are used to assess the validity of correlating deformational phases on the basis of structural evidence.
\end{abstract}

Breemen, O. van, Isotope Geology Unit, Scottish Universities Research and Reactor Centre, East Kilbride, Glasgow G75 OQU, Scotland.

Bowes, D. R., Department of Geology, University of Glasgow, Glasgow G12 8QQ, Scotland.

\section{Introduction}

On the basis of age determinations on syntectonic intrusions (1930-1900 m.y.) and post-tectonic intrusions (1850-1800 m.y.), the time span of the orogenic episode of the Svecokarelian orogenic cycle was about 150 m.y. (Kouvo 1975). During this period both the schists of Karelia and adjacent regions, and the gneisses of southern Finland were affected by polyphase deformation with at least seven deformational phases recognised in the schists and even more in the gneisses (Gaál et al. 1975, Bowes 1976, Hopgood et al. 1976). In places it has been possible to relate the successive emplacement of igneous masses to the deformational sequence. This, together with the dating of these masses, raises the possibility of determining whether apparently corresponding deformational phases, correlated on structural grounds (Hopgood and Bowes, 1972; Bowes, 1975) from different regions, were co-evel or whether the deformational history showed marked diachronism. In addition to elucidating crustal history, such information may provide a basis for correlating across major tectonic or lithological boundaries, or younger orogenic belts such as the Caledonides. The occurrence, about 6 $\mathrm{km}$ NNE of Sivakkavaara (Fig. 1; Geological Map of Finland - Sheet 4311) of large books of muscovite, up to $5 \mathrm{~cm}$ across in a quartzofeldspathic pegmatite whose position in the structural sequence can be demonstrated, forms the basis for one such set of data. 

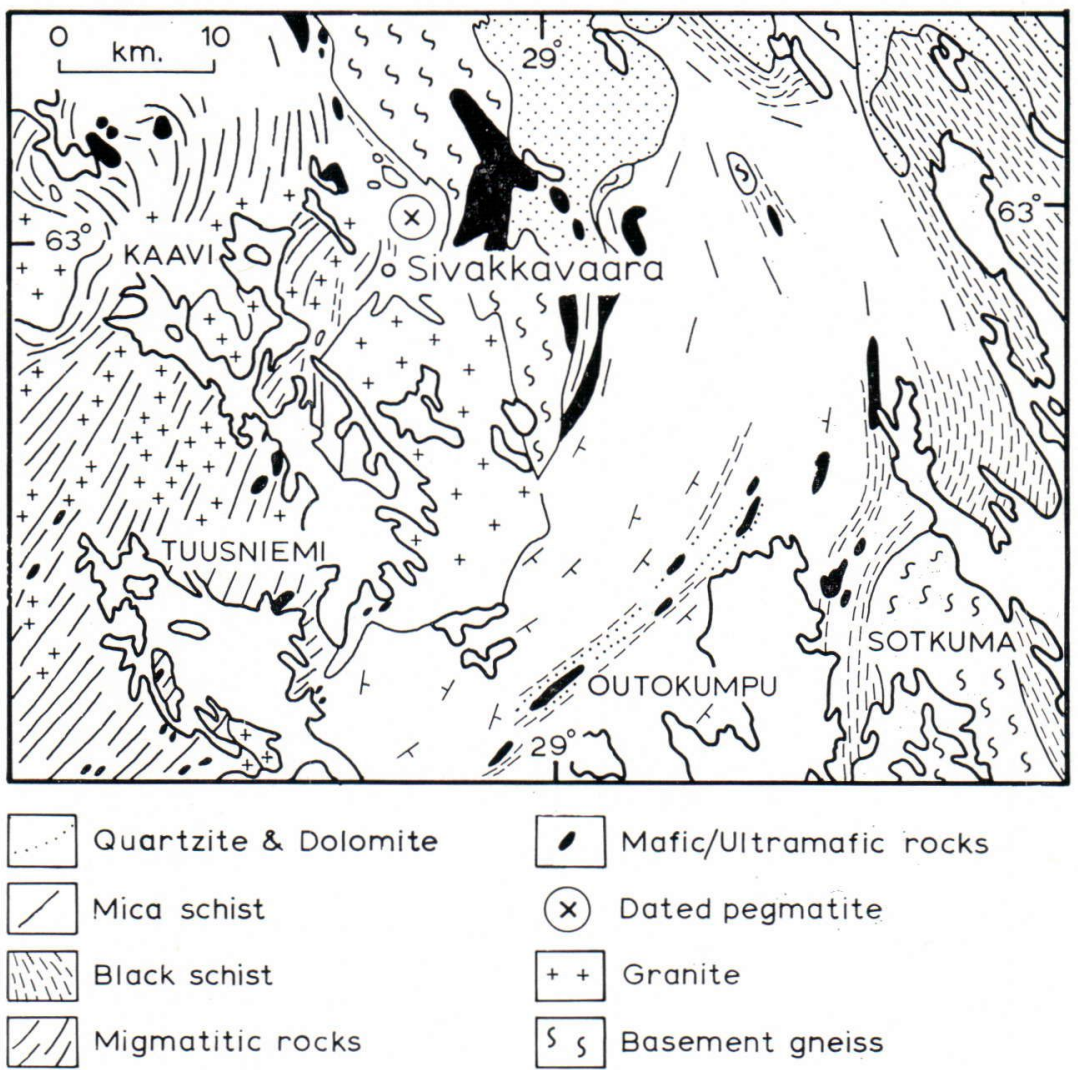

- Mafic/Ultramafic rocks

(x) Dated pegmatite

++ Granite

Ss Basement gneiss

Fig. 1. Outline geological map of the region around Sivakkavaara.

\section{Geological setting}

The host rocks of the pegmatite are amphibolite facies siliceous mica schists in which schistosity in the first deformational phase is reinforced during the second phase to produce a composite schistosity ( $\mathrm{S}_{1 / 2}-$ Fig. 2). This structural element is deformed by open asymmetrical to symmentrical and generally upright folds $\left(\mathrm{F}_{3}\right)$ which plunge at low angles SSE or NNW. These folds are related to those which impart the dominant trend to this part of the Karelian belt ( $\mathrm{F}_{3}$ of Bowes 1975, $\mathrm{F}_{4}$ in the Outokumpu district — Gaál et al. 1975). Axial planar cleavage is locally developed, particularly in axial zones. The pegmatite containing the large muscovite books can be related to a set of smaller interconnecting

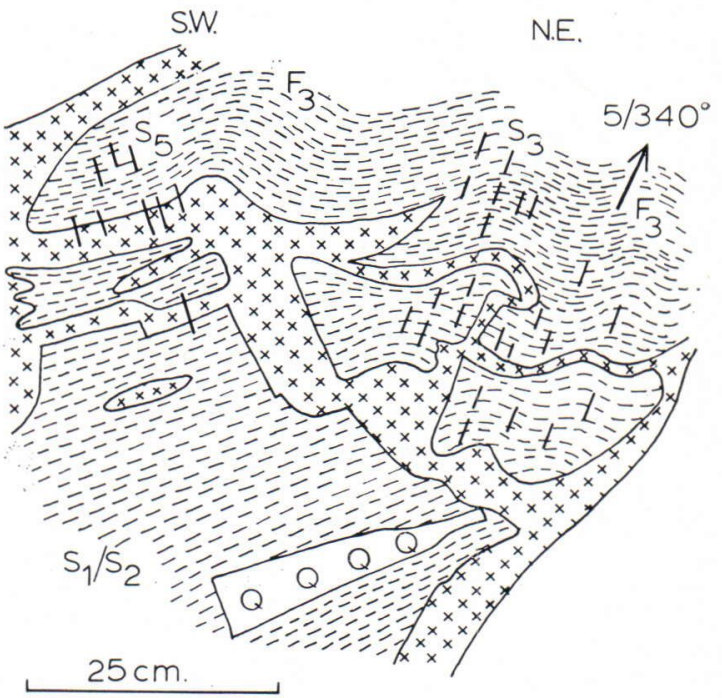

Fig. 2. Relations of pegmatite veins to structures in quartz-mica schist, $6 \mathrm{~km}$ NNE of Sivakkavaara $\left(\mathrm{S}_{4}\right.$ parallel to exposure face). 
veins that show marked structural control of emplacement by $\mathrm{F}_{3}$ fold hinge zones and the $\mathrm{S}_{1 / 2}$ schistosity surfaces (Fig. 2). These veins can be traced for $130 \mathrm{~m}$, either as generally parallel units or as one coalesced mass which is up to $1 \mathrm{~m}$ thick. Both $\mathrm{NE}-\mathrm{SW}$ - and E-W- trending near vertical fractures cut the pegmatite and these can be traced into cleavages $\left(\mathrm{S}_{4}, \mathrm{~S}_{4}\right)$ in the host schists which are axial planar to open, upright folds of the fourth and fifth deformational phases, respectively. In the surrounding area an even later weakly developed cleavage $\left(\mathrm{S}_{6}\right)$ affects the host rocks. Accordingly while the pegmatite emplacement occurred after both the dominant penetrative metamorphic fabric was formed and the dominant regional trend was imposed, it was followed by at least three deformational phases during which temperature was sufficiently elevated for metamorphic mineral growth to occur.

\section{Analytical data}

The analytical methods follow those given by van Breemen et al. (1974). Analytical results for the five samples, and three duplicates, are set out in Table 1 together with the calculated ages. The concentrations of normal $\mathrm{Sr}$ (calculated with ${ }^{87} \mathrm{Sr} /{ }^{86} \mathrm{Sr}=0.71$ ) were extremely low ranging from 1.21 to $0.34 \mathrm{ppm}$.
Accordingly the choice of initial ratios does not influence the calculated ages. The uncertainties quoted are based only on the reproducibility of ${ }^{87} \mathrm{Rb} /{ }^{86} \mathrm{Sr}(2 \sigma=1.4 \%)$. Discrepancies in the duplicate measurements of samples B and D are slightly in excess of what could be expected from the analytical uncertainties alone and are attributed to sample inhomogeneity (samples were only partially ground). However, the wide range of ages obtained for the different books, from 1882 m.y. (D) to 1758 m.y. (C) is far in excess of differences between duplicates.

\section{Discussion}

In view of the high present ${ }^{87} \mathrm{Sr} /{ }^{86} \mathrm{Sr}$ ratios, the scatter in ages cannot be attributed to variation in initial isotopic ratios and must, therefore, be interpreted in terms of radiogenic Sr loss. However, the work of Long and Lambert (1963) and van Breemen et. al. (1974) has shown that in large muscovite books radiogenic $\mathrm{Sr}$ can be retained during amphibolite facies metamorphism. Thus the scatter of ages is interpreted as indicative of a minimum age of $1880 \mathrm{~m} . y$. for pegmatite emplacement, with loss of radiogenic strontium during at least the succeeding 120 m.y., i.e. to 1760 m.y. ago or even later. Such loss implies that temperatures must have remained eleva-

Table 1: Isotopic data for muscovite books

\begin{tabular}{|c|c|c|c|c|c|c|}
\hline Sample & $\begin{array}{c}\mathrm{Rb} \\
(\mathrm{ppm})\end{array}$ & $\begin{array}{c}87 \mathrm{Sr} \\
\text { radiogenic } \\
(\mathrm{ppm})\end{array}$ & $\begin{array}{c}\text { Sr normal } \\
(\mathrm{ppm})\end{array}$ & ${ }^{87 \mathrm{Rb} / 86 \mathrm{Sr}}$ & ${ }^{87 \mathrm{Sr} / 86 \mathrm{Sr}}$ & $\begin{array}{c}\text { Age } \\
(\mathrm{m} . \mathrm{y} .)\end{array}$ \\
\hline $\mathrm{A}$ & 1,085 & 7.86 & 1.12 & 2,792 & 72.18 & $1818 \pm 25$ \\
$\mathrm{~B}$ & 1,401 & 10.30 & 0.34 & 12,060 & 313.9 & $1845 \pm 26$ \\
$\mathrm{~B}$ & 1,387 & 9.94 & 0.40 & 9,973 & 253.2 & $1798 \pm 25$ \\
$\mathrm{C}$ & 976 & 6.83 & 0.66 & 4,309 & 107.3 & $1758 \pm 25$ \\
$\mathrm{C}$ & 968 & 6.77 & 0.65 & 4,315 & 107.4 & $1757 \pm 25$ \\
$\mathrm{D}$ & 1,258 & 9.34 & 1.21 & 3,011 & 79.66 & $1862 \pm 26$ \\
$\mathrm{D}$ & 1,210 & 9.18 & 1.19 & 2,931 & 79.23 & $1902 \pm 27$ \\
$\mathrm{E}$ & 1,242 & 8.81 & 0.57 & 6,349 & 159.9 & $1782 \pm 25$ \\
\hline
\end{tabular}

${ }^{87} \mathrm{Rb}=1.39 \times 10^{-11} \mathrm{yr}^{-1}$ 
ted over this period, which could correspond with that of subsequent deformational phases during which there was some new metamorphic mineral growth.

The age for the end of metamorphic activity, deduced from the ages of the muscovite books is younger than the c. $1850-1800 \mathrm{~m}$.y. range of granitic intrusions in Finland referred to as post-tectonic. However, it at least partly overlaps the c. $1785-1740 \mathrm{~m}$.y. range given by Stephansson (1975) for the late kinematic intrusions of the Svecokarelian episode in Central Sweden. The minimum age of 1880 m.y. for the pegmatite at Sivakkavaara is close to that of c. $1925 \mathrm{~m}$.y. for syn-orogenic basic and ultrabasic intrusions (Gaál 1972) at Kotalahti which are considered to have been emplaced during the regionally expressed third deformational phase. Thus the isotopic data lends support to the correlation of structural sequences over a distance of 80 km (cf. Hopgood and Bowes 1972). However, the post $\mathrm{F}_{3}$ pegmatites at Sivakkavaara are considerably older than pegmatites emplaced $1720 \pm 10$ m.y. ago into a corresponding position in the structural sequence of the Laxfordian orogenic episode of Scotland (Bowes 1975; Lyon et al. 1973; age reduced by one per cent, see van Breemen et al. 1974). Whether this age difference is evidence of diachronism or separate development must await further study, as must detailed knowledge of the ages through the complete deformational sequence of the Svecokarelian episode in Finland.

Acknowledgements - The Isotope Geology Unit at the Scottish Universities Research and Reactor Centre is supported by the Natural Environmental Research Council. Field grants from the University of Glasgow to one of us (D.R.B.) are gratefully acknowledged.

\section{References}

Bowes, D. R. (1975). Scotland - Finland Precambrian correlations. Bull. Geol. Soc. Finland 47: $1-12$.

Bowes, D. R. (1976). Tectonics in the Baltic Shield in the period 2000-1500 million years ago. Acta Geol. Polon. 26: 355-376.

Breemen, O. van, Pidgeon, R. T. and Johnson, M. R. W. (1974). Precambrian and Palaeozoic pegmatites in the Moines of northern Scotland. J. Geol. Soc. Lond. 130: 493-507.

Gaál, G. (1972). Tectonic control of some Ni-Cu deposits in Finland. 24th Int. Geol. Congr. 4: $215-224$.

Gaál, G., Koistinen, T. and Mattila, E. (1975). Tectonics and stratigraphy of the vicinity of Outokumpu, North Karelia, Finland. Geol. Surv. Finland, Bull. 271. 67 p.

Hopgood, A. M. and Bowes, D. R. (1972). Application of structural sequence to the correlation of Precambrian gneisses, Outer Hebrides, Scotland. Bull. Geol. Soc. Amer. 83: 107-128.
- - and Addison, J. (1976). Structural development of the migmatites near Skåldö, Southwest Finland. Bull. Geol. Soc. Finland 48 (1-2): $43-62$.

Kouvo, O. (1975). Geological Survey of Finland. Annual report on activities for the year 1974. Otaniemi.

Long, L. E. and Lambert, R. St. J. (1963) Rb-Sr isotopic ages from the Moine Series. In The British Caledonides. Ed. by M.R.W. Johnson and F. H. Stewart. Oliver and Boyd, Edinburgh.

Lyon, T. D. B., Pidgeon, R. T., Bowes, D. R. and Hopgood, A. M. (1973). Geochronological investigation of the quartzofeldspathic rocks of the Lewisian of Rona, Inner Hebrides. J. Geol. Soc. Lond. 129: 389-404.

Stephansson, O. (1975). Polydiapirism of granitic rocks in the Svecofennian of Central Sweden. Precambr. Res. 2: 189-214.

Manuscript received, June 12, 1975. 